\title{
Effect of supplementing a fibre basal diet with different nitrogen forms on ruminal fermentation and microbial growth in an in vitro semi- continuous culture system (RUSITEC)
}

\author{
M. D. Carro ${ }^{1 *}$ and E. L. Miller ${ }^{2}$ \\ ${ }^{1}$ Departamento de Producción Animal I, Universidad de León, 24071 León, Spain \\ ${ }^{2}$ Department of Clinical Veterinary Medicine, University of Cambridge, Nutrition Laboratory, 307 Huntingdon Road, \\ Cambridge CB3 OJQ, UK
}

(Received 21 September 1998 - Revised 15 February 1999 - Accepted 14 April 1999)

\begin{abstract}
Incubation trials were carried out with the rumen simulation technique (RUSITEC) to study the effects of four forms of $\mathrm{N}$ on the growth of ruminal micro-organisms and the fermentation variables when an all-fibre basal diet was incubated. The basal diet consisted of $10 \mathrm{~g}$ neutraldetergent fibre (NDF) from grass hay plus $2 \mathrm{~g}$ NDF from sugarbeet pulp. $\mathrm{N}$ forms were isolated soyabean protein, soyabean peptides, amino acids blended to profile soyabean protein and $\mathrm{NH}_{3}$ as $\mathrm{NH}_{4} \mathrm{Cl}$. Half of the daily $\mathrm{N}$ supply was infused as $\mathrm{NH}_{4} \mathrm{Cl}$ and the other half was infused as each of the four treatments described. Non- $\mathrm{NH}_{3} \mathrm{~N}(\mathrm{NAN})$ forms increased NDF $(P=0 \cdot 006)$, acid-detergent fibre $(P=0.003)$ and cellulose $(P=0.015)$ disappearance after $48 \mathrm{~h}$ incubation, $\mathrm{CO}_{2}(P<0.001)$, $\mathrm{CH}_{4}(P=0.002)$ and total volatile fatty acids production $(P<0.001)$, as well as the molar percentages of isobutyrate, isovalerate and valerate, which reflected the fermentation of amino acid $\mathrm{C}$ skeletons. NAN treatments also increased microbial $\mathrm{N}$ flow $(P<0.001)$ compared with $\mathrm{NH}_{3}$, with peptides and protein supporting more $(P=0.036)$ than amino acids. The proportion of microbial $\mathrm{N}$ derived from $\mathrm{NH}_{3}$ decreased successively $(P<0.05)$ with $\mathrm{NH}_{3}>$ amino acids $>$ peptides $>$ protein treatments, indicating preferential uptake of peptides without passage through the $\mathrm{NH}_{3}$ pool. Microbial efficiency (g microbial N/kg organic matter apparent disappearance) was greater $(P=0.002)$ for the NAN forms than for the $\mathrm{NH}_{3}$ treatment, with peptides and protein treatments supporting higher $(P=0.009)$ values than amino acid treatment. These results indicate that $\mathrm{N}$ forms other than $\mathrm{NH}_{3}$ are required for optimal fibre digestion and microbial growth.
\end{abstract}

Nitrogen: Microbial protein synthesis: RUSITEC

In spite of the amount of research conducted to characterize the $\mathrm{N}$ metabolism of rumen bacteria, the $\mathrm{N}$ requirements for optimum growth of the mixed bacterial population remain unclear. Several studies (Nolan \& Leng, 1972; Russell et al. 1983; Argyle \& Baldwin, 1987) have shown that although the mixed bacterial population uses $\mathrm{NH}_{3}$ as its main source of $\mathrm{N}$, it may also use pre-formed amino acids or peptides if these are available. Thus, providing non- $\mathrm{NH}_{3} \mathrm{~N}$ (NAN; amino acids, peptides, protein) in addition to $\mathrm{NH}_{3}$ has been shown to stimulate the growth of rumen bacteria in vivo (Chikunya et al. 1996) and in vitro (Cruz Soto et al. 1994), and to enhance digestion of fibre in vivo (McAllan, 1991) and in continuous culture (Merry et al. 1990; Griswold et al. 1996). In contrast, no difference either in digestion or in growth of rumen microbes was found in other in vivo (Fujimaki et al. 1989) and in vitro (Kernick, 1991) studies.
These contrasting results could be explained by differences in the composition of the diet. In most of the studies from which a positive response to pre-formed amino acids and peptides was reported, diets contained a substantial proportion of rapidly fermented carbohydrates, suggesting that rumen fermentation would be stimulated only when the rate of provision of energy permitted (Cruz Soto et al. 1994). Thus, Cruz Soto et al. (1994) found that addition of peptides and amino acids had no effect on the in vitro rate of hydrolysis of cellulose when bacteria were grown on cellulose, although the growth rate of bacteria was stimulated when they were grown on a medium containing cellobiose or glucose.

Because cellulose is the most abundant component of plant cell walls, ruminal cellulolytic bacteria play a central role in the nutrition of ruminant animals fed on diets based

\footnotetext{
Abbreviations: ADF, acid-detergent fibre; LAB, liquid-associated bacteria; NAN, non-ammonia nitrogen; NDF, neutral-detergent fibre; RUSITEC, rumen simulation technique; SAB, solid-associated bacteria; TB, total bacteria; VFA, volatile fatty acids.

*Corresponding author: Dr Dolores Carro, fax +34 987 291311, email DP1MCT@UNILEON.ES
} 
on forages. However, in spite of the conflicting results reported in the literature, the Cornell net carbohydrate and protein system (Russell et al. 1992) assumes that the bacteria fermenting structural carbohydrates (cellulolytic) use only $\mathrm{NH}_{3}$ as the source of $\mathrm{N}$. This point should be clarified, since it is of importance for the accuracy of prediction models of feed evaluation and animal response, as well as for the good use of non-protein $\mathrm{N}$ compounds in the practical feeding of ruminants. The objective of the present study was to investigate the effects of protein, peptides, amino acids and $\mathrm{NH}_{3}$ on microbial growth and fermentation of an all-fibre basal diet in a semi-continuous culture system (RUSITEC; Czerkawski \& Breckenridge, 1977). Some of this work has been briefly published elsewhere (Carro \& Miller, 1998).

\section{Materials and methods}

\section{Apparatus}

The study was carried out using the rumen simulation technique RUSITEC (Czerkawski \& Breckenridge, 1977). The complete unit consisted of eight vessels with an effective volume of $700 \mathrm{ml}$ each and the general incubation procedure was as described by Czerkawski \& Breckenridge (1977). The inoculum was obtained from three ruminally fistulated sheep fed on a good-quality hay $(175 \mathrm{~g}$ crude protein $/ \mathrm{kg} \mathrm{DM}$ and $476 \mathrm{~g}$ neutral-detergent fibre (NDF)/kg DM) diet at maintenance level (Agricultural and Food Research Council, 1993). Rumen content was collected through the rumen fistula immediately before feeding in the morning and transferred to the in vitro system within $30 \mathrm{~min}$ as previously described (Carro et al. 1992). The flow through the vessels was maintained by continuous infusion of McDougall (1948) artificial saliva ( $\mathrm{pH} \mathrm{8.4)} \mathrm{at} \mathrm{a} \mathrm{rate} \mathrm{of} 480 \mathrm{ml} / \mathrm{d}$ (dilution rate of $0 \cdot 029 / \mathrm{h}) . \mathrm{S}\left(\mathrm{Na}_{2} \mathrm{SO}_{3}\right)$ was added to the artificial saliva at a $\mathrm{N}: \mathrm{S}$ ratio of $10: 1$ to prevent a limitation of $\mathrm{S}$ for the synthesis of S-containing amino acids. In order to stimulate the growth of cellulolytic bacteria, isobutyric, isovaleric and valeric acids were also added to the artificial saliva to achieve concentrations of $0.3,0.9$ and $0.7 \mathrm{mmol} / 1$ respectively (Hume, 1970). On day 9, a dose of $1.8 \mathrm{mg}{ }^{15} \mathrm{~N}$ (95\% enriched $\left({ }^{15} \mathrm{NH}_{4}\right)_{2} \mathrm{SO}_{4}$; Sigma Chemical Co., Poole, Dorset, UK) was added into each vessel to label instantaneously the $\mathrm{NH}_{3} \mathrm{~N}$ pool. Then a solution of $\left({ }^{15} \mathrm{NH}_{4}\right)_{2} \mathrm{SO}_{4}$ was added to the artificial saliva at a daily rate of $6.30 \mu \mathrm{g}{ }^{15} \mathrm{~N} / \mathrm{mg} \mathrm{NH} \mathrm{N}_{3} \mathrm{~N}$.

\section{Diets, experimental procedure and sampling}

The diet consisted of NDF (Goering \& Van Soest, 1970) from grass hay and sugarbeet pulp and a commercial mineralvitamin mixture. The diet was supplied to the incubation vessels in nylon bags which contained $10 \mathrm{~g}$ (DM) hay NDF, $2 \mathrm{~g}$ (DM) sugarbeet pulp NDF and $20 \mathrm{mg}$ mineral-vitamin mixture. The amount of $\mathrm{N}$ supplied by the supplements in all treatments was fixed at a rate of $280 \mathrm{mg} \mathrm{N} / \mathrm{d}$. This amount was considered adequate as judged by the concentration of $\mathrm{NH}_{3}$ in the liquid phase of the vessels. In addition the fibre sources in the diet supplied $110 \mathrm{mg} \mathrm{N} / \mathrm{d}$. Four forms of $\mathrm{N}$ were evaluated: (1) protein (commercial isolated soyabean protein; SUPRO ${ }^{\circledR} 500 \mathrm{E}$, Protein Technologies International, Corby, Northants, UK), (2) peptides (enzyme hydrolysate of soyabean protein; Peptone, SigmaAldrich Química, Sociedad Anónima, Spain), (3) amino acids (individual amino acids blended to profile soyabean protein) and (4) $\mathrm{NH}_{3}$ as $\mathrm{NH}_{4} \mathrm{Cl}$. Solutions of each $\mathrm{N}$ treatment were prepared and mixed every day with the artificial saliva. Half $(50 \%)$ of the daily $\mathrm{N}$ supply was infused as $\mathrm{NH}_{4} \mathrm{Cl}$ and the other half $(50 \%)$ was infused as one of the four treatments (protein, peptides, amino acids and $\mathrm{NH}_{4} \mathrm{Cl}$ ). In order to prevent microbial growth in the infusion solutions, the bottles containing the solutions were held in an ice-water bath.

Two identical incubation runs were carried out independently and treatments were assigned randomly within each experimental run so that two vessels received each of the treatments. Therefore each treatment was conducted in quadruplicate. Each incubation run consisted of $14 \mathrm{~d}$ and every day one liquid sample from each vessel was taken daily before feeding and the $\mathrm{pH}$ was measured immediately.

On days 9, 10 and 11 the following samples were collected. The gas produced was collected daily in hermetic bags to determine the gas production and the concentrations of $\mathrm{CO}_{2}$ and $\mathrm{CH}_{4}$. Liquid effluent was collected daily in containers containing a solution of $\mathrm{H}_{2} \mathrm{SO}_{4}(200 \mathrm{ml} / \mathrm{l})$ to maintain $\mathrm{pH}$ values below 2. Effluent $(1 \mathrm{ml})$ was added to $1 \mathrm{ml}$ deproteinizing solution $(100 \mathrm{~g} / \mathrm{l}$ metaphosphoric acid and $0.6 \mathrm{~g} / \mathrm{l}$ crotonic acid) for determination of volatile fatty acids (VFA) and $5 \mathrm{ml}$ effluent was diluted with $5 \mathrm{ml} 0.5 \mathrm{M}-\mathrm{HCl}$ for $\mathrm{NH}_{3}-\mathrm{N}$ determination. One nylon bag from each vessel was collected daily, washed twice with $40 \mathrm{ml}$ artificial saliva and then washed in the cold rinse cycle $(20 \mathrm{~min})$ of a washing machine. DM disappearance after $48 \mathrm{~h}$ incubation was calculated from the loss in weight after oven-drying at $60^{\circ}$ for $48 \mathrm{~h}$, and the residues were analysed for N, NDF, aciddetergent fibre (ADF) and acid-detergent lignin. On day 12 fluid vessel contents were sampled (about $1.5 \mathrm{ml}$ ) at $0,4,8$ and $12 \mathrm{~h}$ after feeding for VFA and $\mathrm{NH}_{3}-\mathrm{N}$ concentrations.

On days 12 and 13 saturated $\mathrm{HgCl}_{2}(5 \mathrm{ml})$ was added (replacing the $\mathrm{H}_{2} \mathrm{SO}_{4}$ solution which could cause bacterial lysis) to the overflow containers, which were held in an icewater bath to impede microbial growth. For each vessel the total effluent for the $2 \mathrm{~d}$ sampling period (days 12 and 13) and the contents of nylon bags which had been removed at the end of these $2 \mathrm{~d}$ were mixed and homogenized in a blender at low speed for $1 \mathrm{~min}$ to reconstitute total digesta. One portion $(300 \mathrm{~g})$ was stored at $-20^{\circ}$ and lyophilized to determine NAN and ${ }^{15} \mathrm{~N}$ enrichment. About $200 \mathrm{~g}$ of the mix was acidified and preserved at $-20^{\circ}$ until $\mathrm{NH}_{3}-\mathrm{N}$ and ${ }^{15} \mathrm{~N}$ enrichment determination, and about $500 \mathrm{~g}$ total digesta was used to isolate bacterial pellets (total bacteria, TB).

On the last day of each incubation trial effluent and fluid vessel contents from the two vessels belonging to the same treatment was collected, mixed with the artificial saliva resulting from washing the nylon bags, and the liquidassociated bacteria (LAB) were harvested. The nylon bag residues (four bags from two vessels) were incubated with $240 \mathrm{ml}$ of a saline solution of methylcellulose (1 g methylcellulose $+9 \mathrm{~g} \mathrm{NaCl}$ in 1 litre distilled water) at $39^{\circ}$ for $30 \mathrm{~min}$ to elute attached bacteria (Minato \& Suto, 1978). Then, $500 \mathrm{ml}$ cold $\left(4^{\circ}\right)$ methylcellulose solution was added, the mixture was homogenized in a blender and stored frozen until isolation of solid-associated bacteria (SAB) pellets. 
$\mathrm{LAB}$ and $\mathrm{SAB}$ pellets were isolated to study possible differences between bacterial fractions in their incorporation of $\mathrm{NH}_{3}-\mathrm{N}$ for the synthesis of protein.

\section{Analytical procedures}

Samples of total digesta (about $1.5 \mathrm{~g}$ ) were wetted with distilled water, adjusted with $1 \mathrm{M}-\mathrm{NaOH}$ to $\mathrm{pH}>10$, and dried at $90^{\circ}$ for $16 \mathrm{~h}$ to remove $\mathrm{NH}_{3}-\mathrm{N}$ (Firkins et al. 1992). The resulting residue was analysed for NAN and for $\mathrm{N}$ insoluble in acid-detergent solution.

$\mathrm{DM}$, ash and $\mathrm{N}$ were determined according to the methods of the Association of Official Analytical Chemists (1995). NDF, ADF and acid-detergent lignin analyses were carried out according to Goering \& Van Soest (1970). Acid-detergent-insoluble $\mathrm{N}$ was determined by Kjeldahl analysis of the ADF residues. $\mathrm{NH}_{3}$ concentration was determined by a modified colourimetric method (Wheatherburn, 1967). VFA were determined in centrifuged samples $(1 \mathrm{ml})$ by GC as previously described (Carro et al. 1992). The volume of gas produced was measured with a drum-type gas meter (model TG1; Ritter Apparatebau GmbH, Bochum, Germany) and the concentrations of $\mathrm{CO}_{2}$ and $\mathrm{CH}_{4}$ were analysed by chromatography as described by Carro et al. (1992). The volume of gas (litres/d) produced was corrected for ambient conditions (pressure $1 \mathrm{~atm}$; temperature $273^{\circ} \mathrm{K}$ ) and the amount of each gas produced $(\mathrm{mmol} / \mathrm{d})$ was calculated.

\section{Isolation of microbial pellets}

The portion of total digesta for isolation of TB was strained through four layers of cheesecloth to remove particulate material. The strained fluid was centrifuged at $500 \mathrm{~g}$ for $10 \mathrm{~min}$ at $4^{\circ}$. The supernatant fraction was then centrifuged at $18000 \mathrm{~g}$ for $25 \mathrm{~min}$ at $4^{\circ}$ to obtain a bacterial pellet. This was washed by resuspension in saline solution $(9 \mathrm{~g} \mathrm{NaCl} / \mathrm{l})$ and the centrifugation was repeated. Finally the bacterial pellet was washed by resuspension in distilled water followed by centrifugation. The isolation of LAB followed the same procedure. Samples for isolation of SAB were thawed, centrifuged at $500 \mathrm{~g}$ for $10 \mathrm{~min}$ at $4^{\circ}$ and the supernatant fraction was removed and retained. Then, $100 \mathrm{ml}$ cold methylcellulose was added to the residue, mixed well and then recentrifuged $\left(500 \mathrm{~g}\right.$ for $10 \mathrm{~min}$ at $\left.4^{\circ}\right)$. This operation was repeated twice, pooling the supernatant fractions each time. The final mixture of pooled supernatant fractions was centrifuged three times at $18000 \mathrm{~g}$ for $25 \mathrm{~min}$ at $4^{\circ}$ as described earlier for TB and LAB isolation. Microscopic examination of final bacterial pellets (TB, LAB and $\mathrm{SAB}$ ) showed that they were essentially free from feed particles. Bacterial pellets were freeze-dried and analysed for $\mathrm{N}$ and ${ }^{15} \mathrm{~N}$ enrichment.

\section{Preparation of samples for ${ }^{15} \mathrm{~N}$ analysis}

The portion of total digesta for $\mathrm{NH}_{3}-\mathrm{N}$ analysis was centrifuged at $20000 \mathrm{~g}$ for $20 \mathrm{~min}$ and the supernatant fraction was analysed for concentrations of $\mathrm{NH}_{3}-\mathrm{N}$ and ${ }^{15} \mathrm{~N}$ enrichment. $\mathrm{NH}_{3}-\mathrm{N}$ concentrations were determined by steam distillation and to prevent cross-contamination a solution of distilled water-ethanol $(2: 1, \mathrm{v} / \mathrm{v})$ was distilled between samples. The distillate was collected in $5 \mathrm{ml}$ boric acid ( $30 \mathrm{ml} / \mathrm{l}$ ), the boric acid acidified with excess $\mathrm{H}_{2} \mathrm{SO}_{4}$ and evaporated down to about $1.5 \mathrm{ml}$ volume on a hot plate at $55^{\circ}$. The dried residue was redissolved in distilled water to give a solution containing an appropriate amount of $\mathrm{N}$ for ${ }^{15} \mathrm{~N}$ analyses. Analyses of ${ }^{15} \mathrm{~N}$ enrichment of the distilled $\mathrm{NH}_{4}{ }^{+}$were performed by isotope-ratio mass spectrometry as described by Barrie \& Workman (1984).

Lyophilized samples of total digesta (about $2 \mathrm{~g}$ ) were treated to remove $\mathrm{NH}_{3}-\mathrm{N}$ (Firkins et al. 1992) and the resulting NAN was collected by micro-Kjeldahl method, distilled as described earlier and prepared for ${ }^{15} \mathrm{~N}$-enrichment determination. Samples of each $\mathrm{N}$ treatment $\left(\mathrm{NH}_{3}\right.$, amino acids, peptides and protein) were analysed for their

${ }^{15} \mathrm{~N}$ content and the natural abundance level of ${ }^{15} \mathrm{~N}$ for each treatment was calculated.

\section{Calculations and statistical analyses}

The proportion of total digesta NAN of microbial origin was estimated by dividing the ${ }^{15} \mathrm{~N}$ enrichment (atom \% excess) of the NAN portion of digesta from each vessel by the enrichment of bacterial pellets (TB). Daily microbial N production $(\mathrm{mg} / \mathrm{d})$ was estimated by multiplying total NAN production by the proportion attributed to the microbes. The proportion of bacterial $\mathrm{N}$ derived from $\mathrm{NH}_{3}-\mathrm{N}$ was estimated by dividing the ${ }^{15} \mathrm{~N}$ enrichment of bacterial pellets by the enrichment of $\mathrm{NH}_{3}-\mathrm{N}$. The amount of microbial $\mathrm{N}$ in the nylon bag residues was estimated as the difference between the NAN content of residues and their acid-detergentinsoluble $\mathrm{N}$ content, assuming that this represents the only $\mathrm{N}$ fraction of feed origin. This value was considered as an estimate of the amount of the SAB. The proportion of $\mathrm{SAB}$ in the daily microbial $\mathrm{N}$ production was calculated by dividing the amount of SAB (estimated as previously described) by the amount of microbial $\mathrm{N}$ (determined using $\mathrm{TB}$ as reference pellets) and the amount of LAB was calculated by difference.

Data relative to fermentation variables were analysed as a split-plot design with $\mathrm{N}$ form and incubation trial as the main-plot treatments and day of sampling as the subplot treatment. Effect of treatment ( $\mathrm{N}$ form) on any of the considered variables was tested using the variance between vessels within treatment and incubation trial as the error term. Microbial flow and efficiency of synthesis data were subjected to ANOVA, with treatment and trial of incubation as main effects. Time-sequence data of VFA and $\mathrm{NH}_{3}$ concentrations in the liquid phase of the vessel were analysed within each time of sampling. The sums of squares were further partitioned by orthogonal contrasts to analyse differences due to $\mathrm{N}$ forms. The contrasts were distributed as follows: $\mathrm{C} 1, \mathrm{NH}_{3} v$. NAN forms; $\mathrm{C} 2$, amino acids $v$. peptide bound amino acids and $\mathrm{C} 3$, peptides $v$. protein. All analyses were conducted using the general linear models procedure of the Statistical Analysis Systems program (1985; Statistical Analysis Systems Inc., Cary, NC, USA).

\section{Results}

The analytical compositions of the two NDF sources and the calculated values for the mixed diet used in RUSITEC are 
Table 1. Chemical composition ( $\mathrm{g} / \mathrm{kg} \mathrm{DM})$ of neutral-detergent fibre from grass hay and sugarbeet pulp and the calculated composition of the incubated basal diet used in the present study

\begin{tabular}{|c|c|c|c|c|c|c|}
\hline Feed component & $\begin{array}{l}\text { Acid-detergent } \\
\text { fibre }\end{array}$ & Hemicellulose & Cellulose & $\begin{array}{l}\text { Acid-detergent } \\
\text { lignin }\end{array}$ & N & $\underset{\mathrm{N}}{\text { Acid-detergent-insoluble }}$ \\
\hline Grass hay & 563 & 437 & 487 & $75 \cdot 8$ & 9.2 & 4.06 \\
\hline Sugarbeet pulp & 498 & 502 & 462 & $36 \cdot 2$ & $15 \cdot 3$ & $5 \cdot 88$ \\
\hline
\end{tabular}

shown in Table 1. There were no incidents, during the RUSITEC trials, except that in the second run one of the vessels presented a small leak and was eliminated. Therefore, mean values for $\mathrm{NH}_{3}$ treatment are the mean of three vessels, whereas data for the other treatments are the mean of four vessels. The effects of $\mathrm{N}$ form on the daily amount of effluent, $\mathrm{pH}$, degradability of the diet and daily gas production are shown in Table 2 . There were no differences $(P>$ $0.05)$ between treatments either in $\mathrm{pH}$ or in the daily amount of effluent, and therefore in the $\mathrm{N}$ supply to the vessels.

NAN forms increased NDF $(P=0.006), \operatorname{ADF}(P=0.003)$ and cellulose $(P=0.015)$ degradability, with no significant differences $(P>0.05)$ between amino acids and peptidebound amino acid forms (peptides and protein) in any of the considered fractions. Degradabilities of ADF $(P=0 \cdot 050)$ and cellulose $(P=0.026)$ were greater for protein than for peptides treatment.

The daily productions of $\mathrm{CO}_{2}$ and $\mathrm{CH}_{4}$ were greater $(P<$ 0.001 and $P=0.002$ for $\mathrm{CO}_{2}$ and $\mathrm{CH}_{4}$ respectively) for the NAN forms $(51.1$ and $12.5 \mathrm{mmol} / \mathrm{d}$ respectively) than for the $\mathrm{NH}_{3}$ treatment $(45 \cdot 1$ and $11.2 \mathrm{mmol} / \mathrm{d}$ respectively). There was no difference $(P>0.05)$ between peptides and protein treatments in the daily production of $\mathrm{CO}_{2}$ and $\mathrm{CH}_{4}$, but these two treatments produced greater amounts of $\mathrm{CO}_{2}$ $(P=0.038)$ and $\mathrm{CH}_{4}(P=0.007)$ than the amino acid treatment.

The effects of $\mathrm{N}$ form on the daily production of VFA, $\mathrm{NH}_{3}-\mathrm{N}$ and NAN are shown in Table 3. NAN treatments increased $(P<0.001)$ total VFA daily production compared with $\mathrm{NH}_{3}$, although there were no differences $(P>0.05)$ among amino acids, peptides and protein treatments. NAN treatments also increased $(P<0.001)$ the daily production of acetate, propionate, butyrate, valerate and isoacids compared with $\mathrm{NH}_{3}$.

There were no statistically significant differences $(P>$ $0 \cdot 05$ ) among the a priori selected treatment contrasts in the daily output of $\mathrm{NH}_{3}-\mathrm{N}$ although values declined in the sequence $\mathrm{NH}_{3}>$ amino acids $>$ peptides $>$ protein. In contrast, the $\mathrm{NH}_{3}$ treatment resulted in a smaller $(P<0.001)$ daily output of NAN than NAN treatments and the amino acid treatment also resulted in a smaller $(P<0.001)$ output of NAN than the peptide and protein treatments. Mean recoveries of $\mathrm{N}$ were $1.01,1.02,0.99$ and 1.00 of $\mathrm{N}$ input for $\mathrm{NH}_{3}$, amino acid, peptides and protein treatments respectively.

The values of the ${ }^{15} \mathrm{~N}$ enrichment of the pellets, $\mathrm{NH}_{3}$ and NAN fraction of the digesta are given in Table 4 . In all treatments the microbial pellets had substantially less ${ }^{15} \mathrm{~N}$ enrichment than that of $\mathrm{NH}_{3}$, indicating incorporation of $\mathrm{N}$ from sources other than the $\mathrm{NH}_{3}$ pool. SAB had less ${ }^{15} \mathrm{~N}$ enrichment than $\mathrm{LAB}$, with TB having intermediate values. As shown in Table 5, NAN forms increased total microbial $\mathrm{N}$ flow $(P<0.001)$ compared with $\mathrm{NH}_{3}$, with peptides and protein supporting more $(P=0.036)$ than amino acids. However, estimates of SAB flow $(\mathrm{mg} / \mathrm{d})$ were greater $(P=0.005)$ for $\mathrm{NH}_{3}$ than for the pooled mean of the other three treatments, with no differences $(P>0.05)$ among them. The proportion of total bacteria in the $\mathrm{SAB}$ fraction was greater $(P<0.001)$ for the $\mathrm{NH}_{3}$ treatment than for the amino acid, peptides and protein treatments. Microbial efficiency, expressed as $\mathrm{g}$ microbial $\mathrm{N} / \mathrm{kg}$ organic matter apparent disappearance, was greater $(P=0.002)$ for the NAN forms

Table 2. Effects of nitrogen form on the amount of effluent, $\mathrm{pH}$, fibre disappearance in $48 \mathrm{~h}$ and daily gas production in the rumen simulation technique (RUSITEC) system

(Treatment values are the mean of three observations in each of four vessels; $n$ 12)

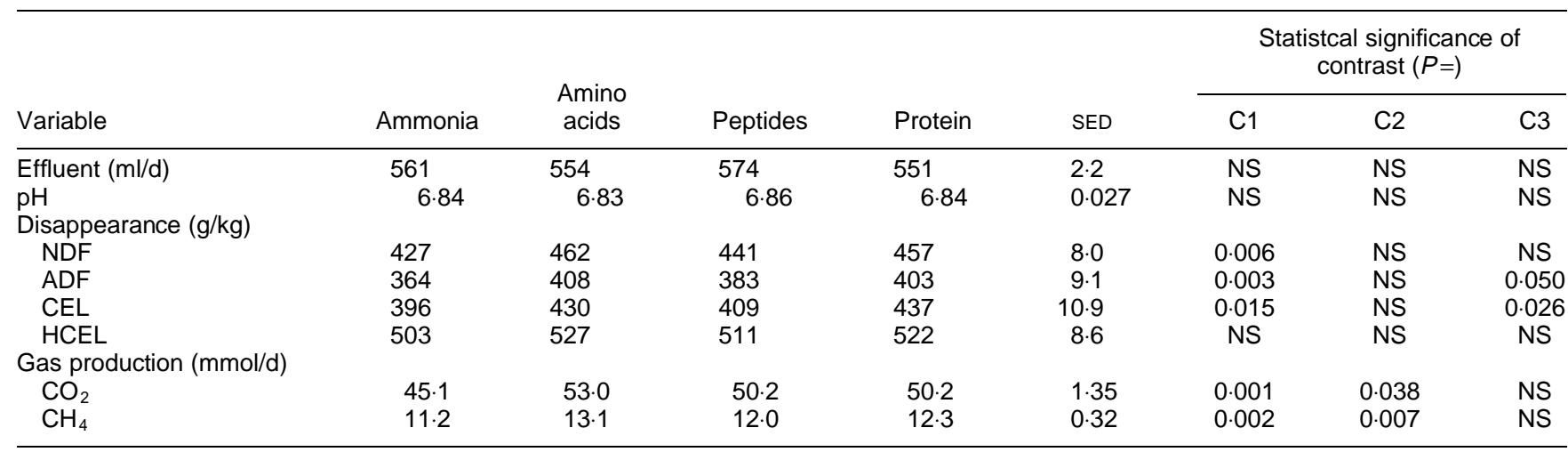

$\mathrm{C} 1, \mathrm{NH}_{3}$ v. non- $\mathrm{NH}_{3} \mathrm{~N}$ forms; C2, amino acids $v$. peptides and protein; C3, peptides $v$. protein; NDF, neutral-detergent fibre; ADF, acid-detergent fibre; CEL, cellulose; HCEL, hemicellulose. 
Table 3. Effects of nitrogen form on the daily production of volatile fatty acids (VFA), ammonia nitrogen and non-ammonia nitrogen (NAN) in the rumen simulation technique (RUSITEC) system

(Treatment values are the mean of three observations in each of four vessels; $n$ 12)

\begin{tabular}{|c|c|c|c|c|c|c|c|c|}
\hline \multirow[b]{2}{*}{ Variable } & \multirow[b]{2}{*}{ Ammonia } & \multirow{2}{*}{$\begin{array}{l}\text { Amino } \\
\text { acids }\end{array}$} & \multirow[b]{2}{*}{ Peptides } & \multirow[b]{2}{*}{ Protein } & \multirow[b]{2}{*}{ SED } & \multicolumn{3}{|c|}{$\begin{array}{c}\text { Statistcal significance of } \\
\text { contrast }(P=)\end{array}$} \\
\hline & & & & & & $\mathrm{C} 1$ & $\mathrm{C} 2$ & $\mathrm{C} 3$ \\
\hline Acetate & 14.7 & $20 \cdot 1$ & $19 \cdot 3$ & $19 \cdot 3$ & 0.42 & 0.001 & NS & NS \\
\hline Propionate & $15 \cdot 7$ & $19 \cdot 4$ & $18 \cdot 2$ & $19 \cdot 8$ & 0.63 & 0.001 & NS & 0.033 \\
\hline Butyrate & $1 \cdot 10$ & $2 \cdot 38$ & 1.94 & 1.81 & 0.178 & 0.001 & 0.008 & NS \\
\hline Isovalerate & 0.46 & 1.40 & 1.23 & $1 \cdot 10$ & 0.119 & 0.001 & 0.047 & NS \\
\hline Total & 33.1 & 45.5 & $42 \cdot \overline{7}$ & 43.8 & 1.29 & 0.001 & NS & NS \\
\hline Acetate: propionate & 0.93 & 1.04 & 1.06 & 0.98 & 0.025 & 0.003 & NS & 0.005 \\
\hline Ammonia-N (mg/d) & 219 & 216 & 195 & 190 & 13.4 & NS & NS & NS \\
\hline NAN $(\mathrm{mg} / \mathrm{d})$ & 175 & 183 & 205 & 200 & 2.9 & 0.001 & 0.001 & NS \\
\hline
\end{tabular}

$\mathrm{C} 1, \mathrm{NH}_{3} v$. non- $\mathrm{NH}_{3} \mathrm{~N}$ forms; C2, amino acids $v$. peptides and protein; $\mathrm{C} 3$, peptides $v$. protein.

than for the $\mathrm{NH}_{3}$ treatment, while peptides and protein treatments resulted in greater $(P=0.009)$ values than the amino acid treatment (18.7 and $16.5 \mathrm{~g}$ microbial $\mathrm{N} / \mathrm{kg}$ organic matter apparent disappearance respectively).

There were also differences $(P=0.002)$ among treatments in the proportion of bacterial $\mathrm{N}$ derived from $\mathrm{NH}_{3}$ (Table 5). When total bacteria were considered, $\mathrm{NH}_{3}$ treatment resulted in the greatest value $(P=0 \cdot 007)$, while the infusion of amino acids, peptides or protein resulted in decreased values indicating reduced uptake of $\mathrm{NH}_{3}$ and direct uptake of amino acids or peptides. For LAB, the $\mathrm{NH}_{3}$ treatment resulted in the greatest $(P<0.001)$ proportion of $\mathrm{N}$ derived from $\mathrm{NH}_{3}$ while the amino acids, peptides and protein treatments produced successively smaller values $(P<0 \cdot 001)$. There

Table 4. Values of ${ }^{15} \mathrm{~N}$ enrichment (atoms \% excess) of bacterial pellets (total bacteria, solid-associated bacteria (SAB) and liquid-associated bacteria (LAB)), the ammonia fraction and the non-ammonia fraction (NAN) of digesta measured in the rumen simulation technique (RUSITEC) system after the infusion of $\left({ }^{15} \mathrm{NH}_{4}\right)_{2} \mathrm{SO}_{4}$ as a microbial marker

(Mean values with their standard errors)

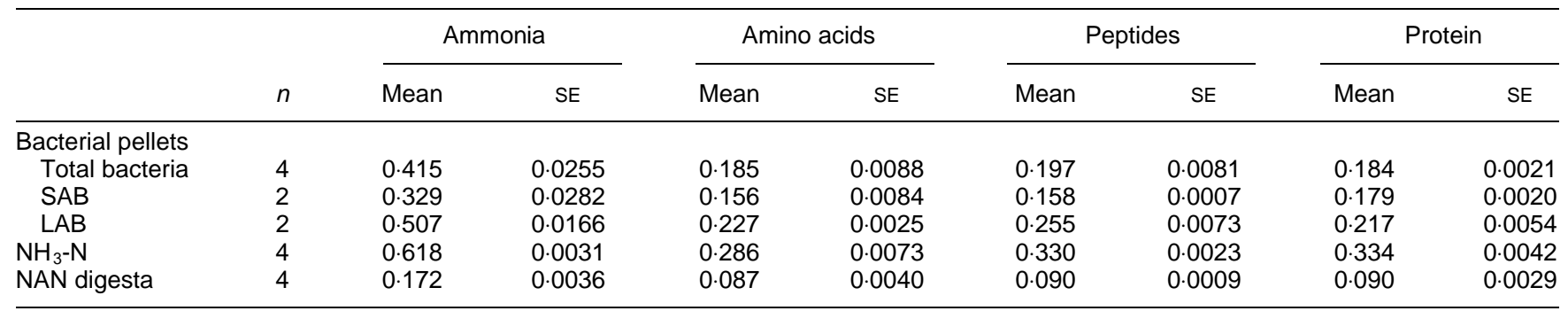

Table 5. Effects of nitrogen form on microbial nitrogen flow and efficiency of microbial synthesis (EMS; $\mathrm{g}$ microbial nitrogen/kg organic matter apparent disappearance) in the rumen simulation technique (RUSITEC) system

(Mean values for four vessels, with the standard error of difference between means)

\begin{tabular}{|c|c|c|c|c|c|c|c|c|}
\hline \multirow[b]{2}{*}{ Variable } & \multirow[b]{2}{*}{ Ammonia } & \multirow{2}{*}{$\begin{array}{l}\text { Amino } \\
\text { acids }\end{array}$} & \multirow[b]{2}{*}{ Peptides } & \multirow[b]{2}{*}{ Protein } & \multirow[b]{2}{*}{ SED } & \multicolumn{3}{|c|}{$\begin{array}{c}\text { Statistical significance of } \\
\text { contrast }(P=)\end{array}$} \\
\hline & & & & & & C1 & $\mathrm{C} 2$ & C3 \\
\hline \multicolumn{9}{|l|}{ Microbial N flow } \\
\hline Total $(\mathrm{mg} / \mathrm{d})$ & $72 \cdot 8$ & $86 \cdot 4$ & 93.7 & $98 \cdot 1$ & 4.54 & 0.001 & 0.036 & NS \\
\hline $\mathrm{SAB}(\mathrm{mg} / \mathrm{d})$ & 35.5 & $32 \cdot 0$ & 32.5 & $32 \cdot 3$ & 0.99 & 0.005 & NS & NS \\
\hline SAB (proportion of total) & 0.490 & 0.370 & 0.347 & 0.330 & 0.0227 & 0.001 & NS & NS \\
\hline \multicolumn{9}{|l|}{$\begin{array}{l}\text { Proportion of microbial } \\
\mathrm{N} \text { derived from } \mathrm{NH}_{3}-\mathrm{N}\end{array}$} \\
\hline Total bacteria & 0.672 & 0.646 & 0.596 & 0.550 & 0.0213 & 0.007 & 0.003 & NS \\
\hline SAB & 0.533 & 0.545 & 0.478 & 0.537 & 0.0200 & NS & NS & 0.015 \\
\hline LAB & 0.821 & 0.794 & 0.773 & 0.651 & 0.0208 & 0.001 & 0.001 & 0.001 \\
\hline
\end{tabular}

$\mathrm{C} 1, \mathrm{NH}_{3}$ v. non- $\mathrm{NH}_{3} \mathrm{~N}$ forms; C2, amino acids $v$. peptides and protein; C3, peptides $v$. protein; SAB, solid-associated bacteria; LAB, liquid-associated bacteria. 
were no differences $(P>0.05)$ among amino acids and peptides and protein treatments in the proportion of SAB$\mathrm{N}$ derived from $\mathrm{NH}_{3}$ (mean value of 0.533 ), but the proportion was smaller $(P=0.015)$ for peptides $(0.478)$ compared with protein $(0.537)$.

Data presented in Figs. 1 and 2 show the changes in relation to feeding time in the $\mathrm{NH}_{3}$ and VFA concentrations in the liquid phase respectively. The pattern of change in $\mathrm{NH}_{3}$ concentrations was similar in all treatments, with the greatest values being recorded just before feeding. The $\mathrm{NH}_{3}$ treatment resulted in greater $(P<0 \cdot 01) \mathrm{NH}_{3}$ concentrations than the pooled NAN treatments at all sampling times. The amino acid treatment had greater $(P<0.001)$ values at all sampling times compared with the peptide and protein treatments, while there was no difference $(P>0.05)$ between peptide and protein treatments. The change in VFA concentrations was also similar in all treatments, but the concentrations were less $(P<0 \cdot 001)$ for the $\mathrm{NH}_{3}$ treatment than for the other three treatments at all sampling

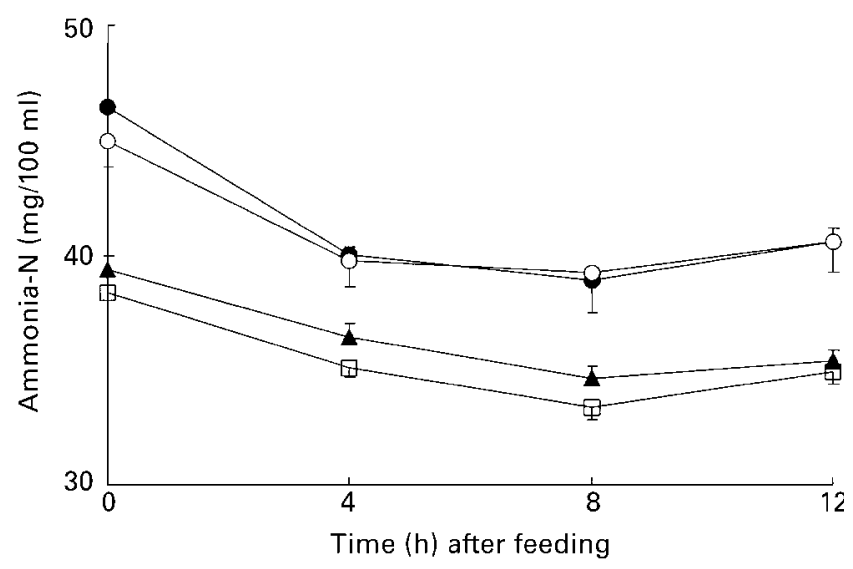

Fig. 1. Effects of nitrogen form (ammonia (๑), amino acids $(O)$, peptides $(\boldsymbol{\Lambda})$ and protein $(\square)$ ) on ammonia- $\mathrm{N}$ concentrations in the vessel fluid in the rumen simulation technique (RUSITEC) system. Values are means for four vessels with their standard errors represented by vertical bars.

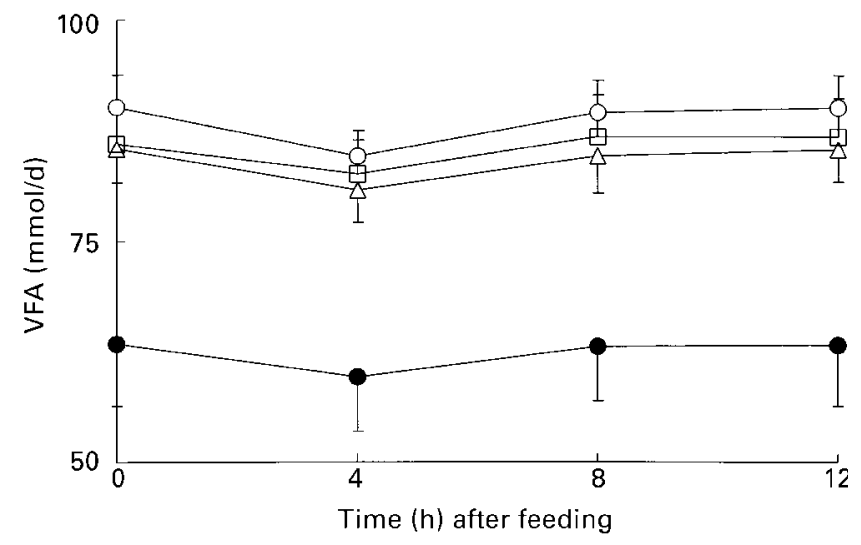

Fig. 2. Effects of nitrogen form (ammonia (๑), amino acids $(O)$, peptides $(\boldsymbol{\Lambda})$ and protein $(\square)$ ) on volatile fatty acids (VFA) concentrations in the vessel fluid in the rumen simulation technique (RUSITEC) system. Values are means for four vessels with their standard errors represented by vertical bars. times, with no differences $(P>0.05)$ among amino acids, peptide and protein treatments.

\section{Discussion}

Cruz Soto et al. (1994) discussed the fact that stimulation of microbial growth by peptides and amino acids would not always occur: the effects may vary depending on the type of carbohydrate (energy substrate) available to the rumen microbes. If bacterial growth rate is limited by the energy source, as on cellulose, the benefits of NAN cannot be realized. On the contrary, if the maximum growth rate is higher, as with rapidly fermented carbohydrates, and is limited by the rate of synthesis of amino acids, stimulation will occur (Cruz Soto et al. 1994). The diet used in our study was intended to contain fibre, with a low, if any, content of non-structural carbohydrates (starches and sugars) in order to stimulate the growth of cellulolytic (structural carbohydrate-fermenting) bacteria. The diet combined rapidly degraded (sugarbeet pulp) and slowly degraded (grass hay) sources of fibre, and therefore a sustainable energy supply was expected.

The Cornell net carbohydrate and protein system (Russell et al. 1992) assumes that bacteria fermenting structural carbohydrates do not utilize peptides or amino acids, but all their $\mathrm{N}$ must come from $\mathrm{NH}_{3}$. This assumption is in conflict with the results of the present study, where disappearance (degradability) of NDF, ADF and cellulose were all increased by the NAN forms. The greater degradability values achieved by the NAN forms are consistent with the greater VFA production values observed for these treatments. The replacement of $\mathrm{NH}_{3}$ by amino acids, peptides and protein increased the daily production of VFA 1.4, 1.3 and 1.3 times respectively, indicating a stimulating effect on the fermentation produced by the NAN forms. Similar results have been reported by Griswold et al. (1996) in an experiment conducted with continuous cultures given a diet consisting of oat straw and maize grain when non-urea $\mathrm{N}$ forms (amino acids, peptides and protein) replaced urea, and by Merry et al. (1990) in a continuous culture system when fishmeal replaced urea in supplementing a barley-straw (50:50, w/w) diet. Molina-Alcaide et al. (1996) reported an increased VFA production when fishmeal replaced urea in supplementing a shrub (Ulex parviflorus) which was fed to continuous fermenters, although the degradability of carbohydrates was not improved.

Part of the increase in VFA production may be due to fermentation of the NAN test substrates. This was probably the major source of the increase in branched-chain fatty acids but, when allowance is made for the additional microbial $\mathrm{N}$ flow, fermentation of the remaining test NAN source is unlikely to account for more than 0.3 of the increase in straight-chain VFA. Consequently, it is concluded that the greater VFA production and increased acetate:propionate ratio (Czerkawski, 1986) found for NAN treatments reflects the improved fibre degradability. Furthermore, the concentrations of isobutyrate, valerate and isovalerate for all treatments (results not shown) were in the range of those reported as adequate for the normal growth of cellulolytic bacteria (Hume, 1970) and the stimulation in fibre degradability and VFA production is ascribed to the 
direct use of amino acids or peptides. However, molar proportions of propionate were greater and those of acetate lower than the ones expected for the fermentation of a fibrous diet. In order to check this unusual VFA pattern a separate trial with batch cultures was carried out. When the hay-NDF was incubated in vitro with buffered ruminal liquid for $48 \mathrm{~h}$ a normal VFA pattern (Czerkawski, 1986) was obtained, but when the sugarbeet pulp-NDF was incubated in vitro under the same conditions the VFA pattern was similar to that found in RUSITEC in the current experiment. Therefore, we concluded that the fermentation of the sugarbeet pulp-NDF prepared for this experiment produced unusually high amounts of propionate and low amounts of acetate. This fact, together with the normal amount of $\mathrm{CH}_{4}$ produced, led to a lack of $\mathrm{H}$ balance, with $\mathrm{H}$ utilization in excess of the theoretical production when calculated according to Czerkawski (1986).

The greater $\mathrm{CO}_{2}$ and $\mathrm{CH}_{4}$ productions observed for the NAN forms are consistent with the improved fibre digestion for these treatments. Gas arises directly from microbial metabolism and indirectly from the reaction of acid endproducts with carbonate salts, an important component of the buffering system, and is related to the amount of feed fermented. The daily $\mathrm{CH}_{4}$ production values, expressed as $\mathrm{mol} / \mathrm{mol}$ VFA, were $0.34,0.29,0.28$ and 0.28 for the $\mathrm{NH}_{3}$, amino acids, peptides and protein treatments respectively, which are similar to values of 0.27 (Czerkawski \& Breckenridge, 1977), 0.23-0.25 (Czerkawski \& Breckenridge, 1979) and 0.27-0.28 (Czerkawski \& Breckenridge, 1982) reported for the fermentation of hay as the only substrate in RUSITEC despite the marked difference in VFA molar ratio in the present experiment.

The determination of bacterial $\mathrm{N}$ flow requires knowledge of a marker: $\mathrm{N}$ ratio in isolated bacteria. However, LAB and SAB not only differ in chemical composition (Merry \& McAllan, 1983; Martín-Orúe et al. 1998) affecting endogenous markers such as diaminopimelic acid, RNA and purine bases but also may take up isotopic markers differentially. In accordance with our results, a greater ${ }^{15} \mathrm{~N}$ enrichment of LAB compared with SAB from infused ${ }^{15} \mathrm{NH}_{4}$ salts has been reported from in vivo (Pérez et al. 1996; MartínOrúe et al. 1998) and in vitro (Komisarczuk et al. 1987) studies. This difference in ${ }^{15} \mathrm{~N}$ enrichment indicates that $\mathrm{SAB}$ take up more of their $\mathrm{N}$ from NAN sources than do LAB. In order to estimate microbial protein synthesis in the rumen an ideal bacterial pellet should be representative of both fractions (SAB and $\mathrm{LAB}$ ). In our experiment the TB pellet was used to estimate microbial production. This pellet was isolated after homogenizing and freezing the digesta, methods which have been used to remove bacteria adhering to feed particles. The mixed TB pellet had an intermediate enrichment between those of SAB and LAB (see Table 4) and appeared to be reasonably representative of the total microbial pool. In agreement with the results reported by other authors (Cruz Soto et al. 1994; Chikunya et al. 1996; Molina-Alcaide et al. 1996; S Chukunya \& EL Miller, unpublished results), total microbial $\mathrm{N}$ flow was significantly increased by all the NAN forms, with the protein treatment producing the greatest values. Values of efficiency of microbial synthesis were in the range reported in the literature for the fermentation of structural carbohydrates
(Czerkawski, 1986; Molina-Alcaide et al. 1996). The greater values for the NAN forms indicate a more efficient microbial growth in the presence of pre-formed amino acids. Furthermore, protein and peptide treatments resulted in a better efficiency of microbial synthesis than amino acid treatment. The amino acid composition of the mixtures (amino acids, peptides and protein) was the same, so presumably the improved growth with peptides and protein reflects more efficient transport into the cell.

The lower uptake of $\mathrm{NH}_{3}$ by SAB compared with LAB may be explained by the substantial residual $\mathrm{N}$ in the feed fibre being used by the SAB in preference to amino acids and peptides in solution. The enrichment of SAB from the $\mathrm{NH}_{3}$ treatment indicates the uptake of $16.6 \mathrm{mg}$ NAN/d which could only have come from the feed fibre. In addition a further $5.6 \mathrm{mg} \mathrm{N} / \mathrm{d}$ was degraded to $\mathrm{NH}_{3}$ (see below) to give a total of $22.2 \mathrm{mg} \mathrm{N} / \mathrm{d}$ or a degradability value of 0.201 . In contrast, the amino acids, peptides and protein infused in the solution may have been degraded by the LAB so rapidly and completely that little actually reached the bacteria in the solid phase. The lack of differences between amino acids and $\mathrm{NH}_{3}$ treatment in the daily production of both $\mathrm{NH}_{3}$ and NAN (Table 3) would indicate an extensive degradation of amino acids, supporting this hypothesis. The $\mathrm{NH}_{3}$ entry rate, calculated from the ${ }^{15} \mathrm{~N}$ enrichment of $\mathrm{NH}_{3}$ (Table 4) by isotope dilution, minus the infused amount of $\mathrm{NH}_{3}$ gives an independent estimate of the degradation of feed NAN to $\mathrm{NH}_{3}$. These estimates are 5.6, 168.9, 127.4 and $118.7 \mathrm{mg}$ $\mathrm{N} / \mathrm{d}$ for $\mathrm{NH}_{3}$, amino acids, peptides and protein treatments respectively which can be compared with the input of 110 and $140 \mathrm{mg} \mathrm{N}$ from the NDF sources and test NAN sources respectively. The contribution to the $\mathrm{NH}_{3}$ entry rate from the NDF sources is unlikely to be the same for all treatments in view of the enhanced NDF digestion with NAN supplements (Table 2) but assuming a constant contribution of $5.6 \mathrm{mg} \mathrm{N} / \mathrm{d}$ gives $\mathrm{NH}_{3}$ entry to amino acids, peptides or protein supply values of $1.16,0.87$ and 0.85 respectively, indicating complete degradation of amino acids and extensive but smaller degradation of peptides and protein supplements to $\mathrm{NH}_{3}$.

The lack of differences between $\mathrm{NH}_{3}$ and NAN forms in the incorporation of $\mathrm{NH}_{3}-\mathrm{N}$ by $\mathrm{SAB}$ seems to indicate that the supply of supplementary amino acids or protein did not reduce $\mathrm{NH}_{3}$ uptake. However, the proportion of $\mathrm{SAB}$ derived from $\mathrm{NH}_{3}-\mathrm{N}$ was significantly lower for the peptide treatment compared with protein, indicating a possible uptake of peptides by the SAB. Nevertheless, the total amount of SAB was not increased by the presence of peptides. On the contrary, $\mathrm{NH}_{3}-\mathrm{N}$ was the treatment which presented the greatest amount of $\mathrm{SAB}$, which could be due to the greater amount of feed residues after $48 \mathrm{~h}$ of incubation with the associated adherent bacteria.

The proportion of LAB-N derived from $\mathrm{NH}_{3}-\mathrm{N}$ was greater for the $\mathrm{NH}_{3}$ treatment than all the others, suggesting that LAB incorporated amino acids and peptides when they were available. The greater LAB-N flow for NAN forms compared with the $\mathrm{NH}_{3}$ treatment (Table 5) also indicates that the growth of these bacteria was stimulated by the presence of pre-formed amino acids. As bacteria fermenting non-structural carbohydrate are usually located in free suspension or loosely associated with feed particles, our 
results agree in this point with the Cornell net carbohydrate and protein system (Russell et al. 1992), which accepted that bacteria fermenting non-structural carbohydrate use either $\mathrm{NH}_{3}$ or peptides and amino acids as an $\mathrm{N}$ form. Russell et al. (1983) reported that when non-structural carbohydrate availability allows growth, 0.66 of the bacterial protein comes from peptides and 0.34 comes from $\mathrm{NH}_{3}$, but when nonstructural carbohydrate is limiting the excess peptide $\mathrm{N}$ is converted to $\mathrm{NH}_{3}$. However, the diets used in the present study contained no non-structural carbohydrate. The LAB in this case must be cellulolytic bacteria or bacteria fermenting secondary products released from NDF by the cellulolytic bacteria. In the Cornell net carbohydrate and protein system the growth of bacteria fermenting structural carbohydrate is dependent on the amount of structural carbohydrate digested including all secondary products. Likewise the growth of bacteria fermenting non-structural carbohydrate is dependent on the amount of starches, sugars and pectin digested with a further adjustment for the stimulation of microbial growth by the availability of peptides. No account is taken of possible stimulation by peptides of microbial growth resulting from the fermentation of secondary products (sugars and organic acids) derived from structural carbohydrates and entering the liquid pool.

In conclusion, where NDF provided the only carbohydrate source, the replacement of $\mathrm{NH}_{3}$ by non- $\mathrm{NH}_{3}$ sources of $\mathrm{N}$ resulted in an increased fibre digestibility and VFA production, as well as an increased flow of microbial $\mathrm{N}$ and efficiency of microbial protein synthesis. These results indicate that $\mathrm{N}$ forms other than $\mathrm{NH}_{3}$ are needed not only for maximum growth of fibre-digesting ruminal microorganisms, but also for maximum fibre digestion.

\section{Acknowledgement}

M. D. Carro acknowledges support of an EU Research Training Fellowship.

\section{References}

Agricultural and Food Research Council (1993) Energy and Protein Requirements of Ruminants. Wallingford: CAB International.

Argyle JL \& Baldwin RL (1987) Effects of amino acids and peptides on rumen microbial growth yields. Journal of Dairy Science 72, 2017-2027.

Association of Official Analytical Chemists (1995) Official Methods of Analysis, 16th ed. Arlington, VA: AOAC.

Barrie S \& Workman CT (1984) An automated analytical system for nutritional investigations using N-15 tracers. Spectroscopy International Journal 3, 439-447.

Carro MD, Lebzien P \& Rohr K (1992) Influence of yeast culture on the in vitro fermentation (Rusitec) of diets containing variable portions of concentrates. Animal Feed Science and Technology 37, 209-220.

Carro MD \& Miller EL (1998) Effect of nitrogen form on growth of rumen micro-organisms in vitro. In In vitro Techniques for Measuring Nutrient Supply to Ruminants. Occasional Publication of the British Society of Animal Science, pp. 303-305. Midlothian: BSAS.

Chikunya S, Newbold CJ, Rode L, Chen XB \& Wallace J (1996) Influence of dietary rumen-degradable protein on bacterial growth in the rumen of sheep receiving different energy sources. Animal Feed Science and Technology 63, 333-340.

Cruz Soto R, Muhammed Samirah A, Newbold CJ, Stewart CS \& Wallace J (1994) Influence of peptides, amino acids and urea on microbial activity in the rumen of sheep receiving grass hay and on the growth of rumen bacteria in vitro. Animal Feed Science and Technology 49, 151-161.

Czerkawski JW (1986) An Introduction to Rumen Studies. Oxford: Pergamon Press.

Czerkawski JW \& Breckenridge G (1977) Design and development of a long-term rumen simulation technique (Rusitec). British Journal of Nutrition 38, 371-384.

Czerkawski JW \& Breckenridge G (1979) Experiments with the long-term rumen simulation technique (Rusitec); response to supplementation of basal rations. British Journal of Nutrition 42, 217-228.

Czerkawski JW \& Breckenridge G (1982) Distribution and changes in urease (EC 3.5.1.5) activity in Rumen Simulation Technique (Rusitec). British Journal of Nutrition 47, 331-348.

Firkins JL, Berger LL, Merchen NR, Fahey GC Jr \& Mulvaney RL (1992) Ruminal nitrogen metabolism in steers as affected by feed intake and dietary urea concentration. Journal of Dairy Science 70, 2302-2314.

Fujimaki T, Kobayashi M, Wakita M \& Hoshino S (1989) Influence of amino acid supplement on cellulolysis and microbial yield in sheep rumen. Journal of Animal Physiology and Animal Nutrition 62, 119-124.

Goering MK \& Van Soest PJ (1970) Forage Fiber Analysis (Apparatus, Reagents, Procedures and Some Applications). Agricultural Handbook, no. 379. Washington, DC: Agricultural Research Services, USDA.

Griswold KE, Hoover WH, Miller TK \& Thayne WV (1996) Effect of form of nitrogen on growth of ruminal microbes in continuous culture. Journal of Animal Science 74, 483-491.

Hume ID (1970) Synthesis of microbial protein in the rumen. II. A response to higher volatile fatty acids. Australian Journal of Agricultural Research 21, 297-304.

Kernick BL (1991) The effect of form of nitrogen on the efficiency of protein synthesis by rumen bacteria in continuous culture. $\mathrm{PhD}$ Thesis, University of Natal.

Komisarczuk S, Durand M, Beaumatin Ph \& Hannequart G (1987) Utilisation de l'azote 15 pour la mesure de la protéosynthèse microbienne dans les phases solide et liquide d'un fermenteur semi-continu (Rusitec) (The use of nitrogen-15 for determination of microbial synthesis in the solid and liquid phases of a semi-continuous fermenter (Rusitec)). Reproduction, Nutrition et Développement 27, 261-262.

McAllan AB (1991) Carbohydrate and nitrogen metabolism in the forestomachs of steers given untreated or ammonia treated barley straw diets supplemented with urea or urea plus fishmeal. Animal Feed Science and Technology 33, 195-208.

McDougall EI (1948) Studies on ruminant saliva. I. The composition and output of sheep's saliva. Biochemical Journal $\mathbf{4 3}$ 99-109.

Martín-Orúe SM, Balcells J, Zakraoui F \& Castrillo C (1998) Quantification and chemical composition of mixed bacteria harvested from solid fractions of rumen digesta: effect of detachment procedure. Animal Feed Science and Technology 71, 269-282.

Merry RJ \& McAllan AB (1983) A comparison of the chemical compositions of mixed bacteria harvested from the liquid and solid fractions of rumen digesta. British Journal of Nutrition 50, 701-709.

Merry RJ, McAllan AB \& Smith RH (1990) In vitro continuous culture studies on the effect of nitrogen source on rumen microbial growth and fibre digestion. Animal Feed Science and Technology 31, 55-64. 
Minato H \& Suto T (1978) Technique for fractionation of bacteria in rumen microbial ecosystem. II. Attachment of bacteria isolated from bovine rumen to cellulose powder in vitro and elution of bacteria attached therefrom. Journal of General and Applied Microbiology 24, 1-16.

Molina-Alcaide E, Weisbjerg MR \& Hvelplund T (1996) Degradation characteristics of shrubs and the effect of supplementation with urea or protein on microbial production using a continuous-culture system. Journal of Animal Physiology and Animal Nutrition 75, 121-132.

Nolan JV \& Leng RA (1972) Dynamic aspects of ammonia and urea metabolism in sheep. British Journal of Nutrition 27, 177-194.

Pérez JF, Rodriguez CA, Gonzalez J, Balcells J \& Guada JA (1996)
Contribution of dietary purine bases to duodenal digesta in sheep. In situ studies of purine degradability corrected for microbial contamination. Animal Feed Science and Technology 62, 251-262.

Russell JB, O'Connor JD, Fox DG, Van Soest PJ \& Sniffen CJ (1992) A net carbohydrate and protein system for evaluating cattle diets: I. Ruminal fermentation. Journal of Animal Science 70, 3551-3561.

Russell JB, Sniffen CJ \& Van Soest PJ (1983) Effect of carbohydrate limitation on degradation and utilisation of casein by mixed rumen bacteria. Journal of Dairy Science 66, 763-775.

Wheatherburn MW (1967) Phenol-hypochlorite reaction for determination of ammonia. Analytical Chemistry 39, 971-974. 